\title{
PENERAPAN ASPEK SPIRITUALITAS-RELIGIUSITAS DALAM KEPUTUSAN BEROBAT DI RUMAH SAKIT ISLAM
}

\author{
Anton Bawono \\ Dosen STAIN Salatiga \\ Email: Alfathbawono@yahoo.co.id
}

\begin{abstract}
This research is trying to observe spirituality-religiousity aspect through marketing mix that influences the patients to choose Islamic hospital. By applying non-profitability sampling in which data is collected through questionaire given to the patients in Rumah Sakit Islam Kalimasada Yogyakarta. The finding on statistical and classical assumption show that spirituality-religiousity aspect is the secondary aspect in making the decision to choose Islamic hospital. So that this aspect play an important role for health organization to compete in health services.
\end{abstract}

Keywords: Marketing Mix, spirituality-religiousity, patients decision.

\begin{abstract}
Abstrak
Artikel ini merupakan hasil penelitian dengan melihat kontribusi aspek spiritualitas-religiusitas dengan marketing mix dalam mempengarubi keputusan pasien berobat di rumab sakit Islam. Metode pengambilan sampel yang digunakan adalab Sampling Non-Probability Sampling, Peneliti melakukan pengumpulan data melalui penyebaran kuesioner (setelab dilakukan uji instrumennya) yang disebarkan pada pasien di pelayanan kesehatan Di Rumah Sakit Islam Kalimasada Yogyakarta.

Setelah melewati uji statistik dan asumsi klasik maka diperoleb kesimpulan babwa aspek spiritualitas-religiusitas merupakan variabel kedua terkuat yang mempengarubi keputusan pasien berobat. Hal ini menunjukkan bahwa pelayanan spiritual-religiusitas di rumah sakit dapat meningkatkan daya tarikpasien yang membutubkan jasa perawatan kesehatan. Sebingga penerapan aspek spiritual-religiusitas yang baik dibarapkan suatu unit usaba pelayanan kesebatan ini dapat memenangkan persaingan usaba dan eksis dalam dunia pelayanan kesehatan.
\end{abstract}

Kata kunci: bauran pemasaran, spiritualitas-religiusitas, keputusan pasien 


\section{Latar Belakang Masalah}

Setiap orang yang beriman dan bertakwa kepada Tuhan meyakini dan mengalami kehadiran Tuhan dalam diri dan kehidupannya. Oleh karena itu seseorang akan berusaha untuk mengenali, mengerti, memahami dan menyadari tanda-tanda kehadiran Tuhan dalam kehidupannya sehari-hari. Sebab iman meresap secara dinamis dalam kehidupan sehari-hari. Iman teraktualisasi dalam kehidupan nyata baik fisik, psikis dan rohani. Maka dari itu setiap orang harus berusaha mengembangkan refleksi iman untuk mawas diri, memperbaharui diri dan menegaskan kembali cara, tanggung jawab dan kewajibannya, serta mengadakan komunikasi iman yang inklusif dan toleran dan pluradialogal dengan semua orang beriman lintas religi dan budaya.

Spiritualitas-religiusitas seseorang juga memiliki peran yang signifikan dalam berbagai tahap perkembangan. Untuk remaja, dikatakan bahwa remaja yang religius cenderung memiliki nilai yang lebih baik di sekolah. Beberapa penelitian juga menunjukkan hubungan antara tingkat religiusitas dengan kemampuan remaja untuk berinteraksi dengan lingkungan. Tidak hanya itu, semakin baik religiusitas remaja, maka semakin baik pula rasa percaya dirinya. Untuk yang sudah menikah, pasangan yang religius juga memiliki periode menikah yang lebih lama. Tidak hanya itu, tingkat kepuasan pernikahan, serta level komitmen mereka juga lebih baik dibanding pasangan yang tidak religius.

Hasil penelitian yang dilakukan selama dua dekade juga menyimpulkan bahwa agama memiliki kaitan dengan kesejahteraan psikologis. Individu dengan konsep agama yang positif memiliki kemungkinan yang lebih kecil untuk mengalami depresi. Selain itu, individu juga akan merasa lebih bahagia dalam menjalani kesehariannya. Penjelasan lain mengemukakan bahwa berdoa mampu mempengaruhi keadaan pikiran serta tubuh. Dengan berdoa, keadaan pikiran akan menjadi tenang, sehingga tubuh juga menjadi rileks, kedua hal tersebut akan mengurangi kecemasan, menurunkan tekanan darah, menstabilkan pola tidur serta melancarkan proses pernafasan serta pencernaan. 
Agama juga membantu proses self-regulation atau pengaturan diri. Dilihat dari sudut pandang psikologi, self-regulation akan membuat individu bertingkah laku sesuai dengan aturan-aturan atau tujuan yang ingin dicapainya tersebut. Oleh karena itu, jika kembali dikaitkan dengan hubungannya dengan kesehatan, agama akan memberikan berbagai aturan untuk menjalani hidup yang sehat. Dengan penanaman aturan-aturan tersebut, individu dengan tingkat religiusitas yang baik akan lebih mampu mengontrol dirinya dalam menjalankan peraturan tersebut. Mereka lebih mampu menolak halhal yang tidak baik, seperti tidak merokok dan minum-minuman keras.

Berkaitan dengan upaya penyembuhan kesehatan aspek spiritualitas religiusitas juga mempunyai pengaruh yang besar. Adanya penyembuhan spiritual dengan cara mendoakan pasien sebelum melakukan tindakan medis atau pengobatan, memutarkan lagu religi atau lagu-lagu rohani serta kelengkapan simbol-simbol keagamaan lain seperti Kitab Suci, Al-Qur'an, lilin ataupun air dan minyak suci. Hal ini akan mempengaruhi nilai religius, keyakinan dan kepercayaan kepada Sang Pencipta dan ternyata faktor iman dan kepercayaan seseorang lebih mampu mengatasi dan proses penyembuhan penyakit lebih cepat. Untuk itu dalam menumbuhkan sikap kereligiusan pasien maka diperlukan adanya penerapan aspek spiritual atau bimbingan rohani bagi pasien dalam suatu pengobatan atau pelayanan kesehatan.

Rumah sakit merupakan pusat pelayanan rujukan medik spesialistik dan sub spesialistik dengan fungsi utama menyediakan dan menyelenggarakan upaya kesehatan yang bersifat penyembuhan (kuratif) dan pemulihan (rehabilitatif) pasien (Depkes, 1989). Sesuai dengan fungsi utamanya tersebut, perlu pengaturan sedemikian rupa sehingga rumah sakit mampu memanfaatkan sumber daya yang dimilikinya dengan lebih berdaya guna (efisien) dan berhasil guna (efektif).

Berawal dan bertolak dari manusia sebagai makhluk ciptaan Tuhan yang dimana nilai religius, keyakinan dan kepercayaan kepada Sang Pencipta yaitu Tuhan Yang Maha Esa, ternyata melalui perwujudan iman dan kepercayaan seseorang telah mampu mendukung dalam proses penyembuhan penyakit atau stress lebih cepat. 
Untuk itu dalam pemberian pelayanan kesehatan di rumah sakit saat ini harus tidak terlepas dengan penerapan aspek spiritual religiusitas oleh seorang dokter ataupun perawat dalam pelayanan pengobatan kepada pasien misalnya dengan memberikan bimbingan doa sebelum atau sesudah pengobatannya, konsultasi keagamaan dan pendalaman keimanan atau kelengkapan simbolsimbol rohani serta hal lain yang serupa. Spiritualitas itu sendiri adalah keyakinan dalam hubungannya dengan yang Maha Kuasa. Sedangkan kebutuhan spiritual adalah kebutuhan untuk mempertahankan atau mengembalikan keyakinan dan memenuhi kewajiban agama, serta kebutuhan untuk mendapatkan maaf atau pengampunan. Kebutuhan spiritual merupakan kebutuhan dasar yang dibutuhkan oleh setiap manusia tidak terkecuali bagi orang yang sakit, stress atau sebagainya.

Seorang dokter atau perawat hendaknya memiliki pengetahuan bahwa manusia sebagai makhluk bio-psiko-sosio-kultural dan spiritual yang tergantung terhadap suatu perubahan yang terjadi antara lain karena gangguan kesehatan dan penyimpangan pemenuhan kebutuhan. Untuk dapat memenuhi kebutuhan secara holistik dan unik diperlukan pendekatan yang komprehensif dan bersifat individual bagi tiap sistem pasien.

Perawat sebagai tenaga kesehatan yang profesional mempunyai kesempatan yang paling besar untuk memberikan pelayanan kesehatan khususnya pelayanan atau asuhan keperawatan yang komprehensif dengan membantu pasien memenuhi kebutuhan dasar yang holistik. Perawat memandang pasien sebagai makhluk biopsikososio-kultural dan spiritual yang berespon secara holistik dan unik terhadap perubahan kesehatan atau pada keadaan krisis. Asuhan keperawatan yang diberikan oleh perawat tidak bisa terlepas dari aspek spiritual yang merupakan bagian integral dari interaksi perawat dengan pasien. Perawat berupaya membantu memenuhi kebutuhan spiritual pasien sebagai bagian dari kebutuhan menyeluruh pasien, antara lain dengan memfasilitasi pemenuhan kebutuhan spiritual pasien tersebut, walaupun perawat dan pasien tidak mempunyai keyakinan spiritual atau keagamaan yang sama (Hamid A.Y., 2000: 3). 
Dalam pelayanan kesehatan di rumah sakit seorang dokter atau perawat hendaknya mampu menanamkan pelayanan yang juga berbasis spiritual religiusitas. Pengalaman-pengalaman religius atau rohani dan pengalaman iman yang terungkap dalam tradisi dan latihan spiritual, ajaran-ajaran etik dan moral serta tradisi iman dalam masing-masing komunitas religius, yang tumbuh dan berkembang dalam religi dan bentuk kepercayaannya harus menjadi modal seorang dokter atau perawat yang selanjutnya dapat disalurkan dan diimplementasikan kepada pasien melalui pengobatan yang diberikan.

Kebutuhan spiritual merupakan kebutuhan dasar yang dibutuhkan oleh setiap manusia. Apabila seseorang dalam keadaan sakit, maka hubungan dengan Tuhannya pun semakin dekat, mengingat seseorang dalam kondisi sakit menjadi lemah dalam segala hal, tidak ada yang mampu membangkitkannya dari kesembuhan, kecuali wujud dan bentuk keyakinan, iman dan kepercayaannya kepada Sang Pencipta. Oleh karena itu seorang perawat hendaknya memiliki peran utama dalam memenuhi kebutuhan spiritual. Di dalamnya dituntut mampu memberikan pemenuhan yang lebih pada saat pasien mengalami sakit keras, pasien kritis pasien yang akan di operasi atau menjelang ajal. Dengan demikian, terdapat keterkaitan antara keyakinan dengan pelayanan kesehatan dimana kebutuhan dasar manusia yang diberikan melalui pelayanan kesehatan tidak hanya berupa aspek biologis, tetapi juga aspek spiritual. Aspek spiritual dapat membantu membangkitkan semangat ataupun keyakinan pasien dalam proses penyembuhannya.

Ketika sedang sakit, stress atau nyeri menyerang seseorang, kekuatan spiritual mampu menciptakan ketenangan sehingga dapat membantu seseorang ke arah penyembuhan atau pada perkembangan kebutuhan dan perhatian spiritual. Selama penyakit atau kehilangan, misalnya saja, individu sering menjadi kurang mampu untuk merawat diri mereka dan lebih bergantung pada orang lain untuk perawatan dan dukungan. Distres spiritual dapat berkembang sejalan dengan seseorang mencari makna tentang apa yang sedang terjadi, yang mungkin dapat mengakibatkan seseorang merasa sendiri dan terisolasi dari orang lain. Individu mungkin memper- 
tanyakan nilai spiritual mereka, mengajukan pertanyaan tentang jalan hidup seluruhnya, tujuan hidup dan sumber dari makna hidup.

Dengan jelas dalam pelayanan kesehatan seorang dokter atau perawat untuk mendapat gambaran tentang dimensi spiritual pasien yang jelas mungkin dibatasi oleh lintas agama dan budaya serta lingkungan dimana orang tersebut mempraktikkan spiritualnya. Hal ini benar jika seorang dokter atau perawat mempunyai kontak yang terbatas dengan pasien dan gagal untuk membina hubungan. Pertanyaannya adalah bukan jenis dukungan spiritual apa yang dapat diberikan tetapi secara sadar mengintegrasikan perawatan spiritual yang disertakan ke dalam proses pengobatan yang diberikan. Oleh karena itu dukungan spiritual dalam harus mempunyai nilai-nilai universal yang kemudian direfleksikan lebih lanjut dengan "kaca mata" religi atau kepercayaan masing-masing terutama pasien sehingga akhirnya mampu menemukan nilai-nilai spiritual religiusitas bagi kehidupannya yang secara tidak langsung berpengaruh pada proses penyembuhan atau pemulihan kesehatannya.

Rumah Sakit Islam Kalimasada Bantul Yogyakarta adalah salah satu rumah sakit yang memberikan pelayanan rujukan medik spesialistik dan sub spesialistik dengan menyediakan dan menyelenggarakan upaya kesehatan yang bersifat penyembuhan (kuratif) dan pemulihan (rehabilitatif) pasien. Dari data yang diperoleh di ruang rawat inap Rumah Sakit Islam Kalimasada Bantul Yogyakarta, data jumlah pasien rawat inap perbulannya pada tahun 2010 sebanyak 300 dengan jumlah perawat di ruang bedah sebanyak 15 orang, di ruang perawatan rawat inap sebanyak 34 orang. Tingkat kunjungan pasien dalam suatu pelayanan kesehatan rumah sakit tentu saja dipengaruhi oleh faktor strategi pemasaran atau marketing mix yang diterapkan. Strategi pemasaran yang tepat akan mempengaruhi keputusan pasien dalam memilih jenis pelayanan kesehatan yang diberikan. Suatu unit usaha tidak terkecuali rumah sakit harus dapat membuat planning yang terbaik, tepat, cermat dan profesional dalam marketing mix karena berhubungan langsung dengan survive atau tidaknya dalam bisnis pelayanan kesehatan. Selain itu, dengan strategi marketing mix (produk, harga, distribusi, dan promosi) yang baik diharapkan suatu unit usaha pelayanan kesehatan ini dapat 
memenangkan persaingan usaha dan eksis dalam dunia pelayanan kesehatan.

Namun dengan begitu pentingnya penerapan aspek spiritual religiusitas dalam pelayanan kesehatan sangat memungkinkan bahwa faktor penerapan aspek spiritual religiusitas akan dapat mempengaruhi pribadi, keyakinan dan nilai-nilai spiritual seseorang. Hal ini tentunya dapat dijadikan sebagai strategi pemasaran yang akan tepat dan dapat mempengaruhi keputusan konsumen atau pasien untuk berobat di rumah sakit, selain dengan strategi pemasaran atau marketing mix.

\section{Permasalahan}

Berdasarkan yang di uraikan latar belakang di atas, maka yang menjadi permasalahan dalam penelitian ini adalah :

1. Apakah ada pengaruh yang signifikan dari faktor marketing mix dan aspek spiritual religiusitas baik secara parsial maupun simultan terhadap keputusan pasien untuk berobat di Rumah Sakit Islam Kalimasada Bantul Yogyakarta?

2. Diantara variabel penerapan aspek spiritual-religiusitas dan dimensi marketing mix, manakah yang paling dominan mempengaruhi keputusan untuk berobat di Rumah Sakit Islam Kalimasada Bantul Yogyakarta?

3. Bagaimanakah faktor marketing mix dan penerapan aspek spiritual religiusitas memperjelas keputusan untuk berobat di Rumah Sakit Islam Kalimasada Bantul Yogyakarta?

\section{Tinjauan Pustaka}

Beberapa hasil penelitian berkaitan dengan pengaruh marketing mix terhadap keputusan pasien, yang penulis dapatkan adalah sebagai berikut:

Penelitian yang dilakukan oleh Adiwijaya (2008), hasilnya menunjukkan bahwa dari unsur marketing mix, maka place yang meliputi jarak dan kemudahan mengakses lokasi tempat jasa pelayanan disediakan yang memiliki kekuatan hubungan paling tinggi yaitu masuk dalam kategori kuat dan unsur promosi yang 
berorientasi pada komunikasi antara penyedia jasa dengan konsumen yang memiliki kekuatan hubungan paling lemah yaitu masuk dalam kategori sangat rendah. Kesimpulan secara umum bahwa unsur marketing mix memiliki hubungan yang signifikan dengan proses keputusan pasien memanfatkan rawat jalan RS Dr Wahidin Sudirohusodo

Taylor dan Baker (1997: 1) melakukan penelitian terhadap pasien pada pelayanan kesehatan yang berorientasi profit dan nonprofit yang dianalisis dengan Multiple Analysis Regression. Ia juga menemukan kepuasan pasien mempengaruhi intensi pembelian pada masa yang akan datang pada pelayanan kesehatan.

Penelitian yang dilakukan oleh Poernomo dan Dewi Ika Sari Hari (2009), hasil penelitan juga menunjukkan adanya pengaruh bersama-sama antara persepsi tentang price dan process terhadap loyalitas pasien. saran bagi manajemen dan bagian marketing untuk menerapkan strategi harga khusus untuk mengikat pelanggan lama, meningkatkan mutu pelayanan di poliklinik terutama untuk process pelayanan, fokus pada kepuasan pasien dan menjalin komunikasi yang baik dengan pasien lama sehingga dapat meningkatkan loyalitas pasien terhadap RS Baptis .

Penelitian yang dilakukan Jetty Trinahayu Nawing (2011), hasil penelitian menunjukkan bahwa secara umum unsur stimuli pemasaran mempunyai pengaruh terhadap keputusan pasien untuk memanfaatkan rawat jalan RS Ibnu Sina, kecuali unsur proses yang tidak memberikan pengaruh signifikan. Selanjutnya, unsur promosi yang berorientasi komunikasi antara penyedia jasa dan konsumen berpengaruh paling dominan.

Hasil temuan Hutton dan Richardson, (1995: 52), bahwa pada rumah sakit lingkungan fisik mencakup lokasi, peralatan dan fasilitas, yang dianggap penting oleh pasien rumah sakit. Lokasi merupakan kestrategisan letak rumah sakit baik dihubungkan dengan fasilitas umum maupun kemudahan untuk mencapainya.

Penelitian yang dilakukan Meisutrisno (2008), Ada pengaruh yang signifikan antara marketing mix dengan keinginan berkunjung ulang pasien di Unit Rawat Inap RS TNI AU Dr. S. Hardjolukito Yogyakarta. Dimensi yang menjadi pendukung utama keinginan 
pasien untuk berkunjung ulang pasien yaitu dimensi place (tempat / lokasi).

Penelitian yang dilakukan oleh Cooper (1994: 392) pada rumah sakit, menemukan bahwa kualitas dokter, fasilitas perawatan dan teknologi, fasilitas diagnosa, kualitas perawatan keseluruhan, perhatian interpersonal, kesadaran staf terhadap kebutuhan personal pasien, kontrol pasien dari pengalaman rumah sakit, lokasi dan biaya, kemudahan dari lokasi berpengaruh terhadap citra rumah sakit.

Beberapa temuan penelitian di atas tidak ada yang memasukkan unsur spiritual-religiusitas. Sehingga menjadi sangat menarik jika penelitian ini mengaitkan marketing mix dengan spiritualitasreligiusitas.

\section{Landasan Teori}

A. Tinjauan Aspek Marketing Mix

Pemasaran atau marketing merupakan unsur yang sangat dominan yang harus diperhatikan oleh pengusaha. Proses marketing sendiri seharusnya sudah dijalankan jauh-jauh hari sebelum barang yang akan dipasarkan tersebut diproduksi. Marketing mix adalah suatu proses sosial dan manajerial yang membuat individu dan kelompok memperoleh apa yang mereka butuhkan, serta ingin lewat penciptaan dan pertukaran timbal balik produk dengan orang lain (Kotler dan Amstrong, 1997: 6).

Marketing mix adalah elemen-elemen organisasi perusahaan yang dapat dikontrol oleh perusahaan dalam melakukan komunikasi dengan konsumen dan akan dipakai untuk memuaskan konsumen (Zeithalm and Bitner, 2001: 18). Kombinasi dari empat variabel atau kegiatan yang merupakan inti dari sistem penawaran perusahaan, yaitu antara lain : Produk, Struktur harga, kegiatan promosi dan distrbusi (Staton William, 1997: 24).

1. Produk

Produk merupakan suatu yang ditawarkan produsen untuk diperhatikan, diminta, dicari, digunakan atau dikonsumsi pasar sebagai pemenuhan kebutuhan atau kegiatan pasar yang bersangkutan (Tjiptono, 1995: 95). Elemen atau kunci penawaran 
pasar atau market offering (Kotler, 1997: 52) merupakan Segala sesuatu yang dapat ditawarkan produsen untuk diperhatikan, diminta, dicari, dibeli dan digunakan atau dikonsumsi pasar sebagai pemenuhan kebutuhan atau keinginan pasar yang bersangkutan ( Kotler, 2000: 428).

2. Harga

Jumlah uang yang ditambah beberapa jumlah kalau mungkin yang dibutuhkan untuk mendapatkan sejumlah kombinasi barang beserta pelayananya (Swasta, 1999: 147). Harga merupakan satuan manometer atau ukuran lainnya (termasuk barang dan jasa) yang ditukarkan agar memperoleh hak kepemilikan atau penggunaan suatu barang dan jasa (Tjiptono, 2001: 151). Penentuan harga merupakan titik kritis dalam bauran pemasaran jasa kerena harga menentukan pendapatan dari suatu usaha bisnis.

3. Distribusi

Satuan yang digunakan produsen untuk menyalurkan barang tersebut dari produsen sampai konsumen atau pemakai industri (Swasta, 1999: 190). Distribusi merupakan kegiatan pemasaran yang berusaha memperlancar dan mempermudah penyampaian barang dan jasa dari produsen kepada konsumen sehingga penggunaannya sesuai dengan jumlah yang diperlukan meliputi jumlah, jenis, harga, tempat, dan saat dibutuhkan (Tjiptono, 2001: 185).

4. Promosi

Promosi merupakan salah satu faktor penentu keberhasilan suatu program pemasaran. Walaupun berkualitasnya suatu barang atau jasa suatu produk bila konsumen belum pernah mendengarnya dan tidak yakin bahwa produk tersebut akan berguna bagi mereka, maka mereka tidak akan pernah membelinya.

\section{B. Tinjauan Umum tentang Aspek Spiritualitas}

Spiritualitas adalah keyakinan dalam hubungannya dengan yang Maha Kuasa. Sebagai contoh, orang yang percaya kepada Allah sebagai Pencipta atau sebagai Maha Kuasa. Menurut Burkhardt (1993), spiritualitas meliputi aspek sebagai berikut : 
1. Berhubungan dengan sesuatu yang tidak diketahui atau ketidakpastian dalam kehidupan.

2. Menemukan arti dan tujan hidup.

3. Menyadari kemampuan untuk menggunakan sumber dan kekuatan dalam diri sendiri.

4. Mempunyai perasaan keterikatan dengan diri sendiri dan dengan Yang Maha Tinggi.

Kualitas hidup rohani atau spiritualitas yang dewasa sebagai orang yang beriman dan bertakwa kepada Tuhan sesuai dengan religi yang dianutnya. Kemampuan untuk mengelola dan mengungkapkan mentalitas, kehendak, perasaan dan karsanya secara benar melalui pendidikan dan latihan-latihan spiritual yang dewasa ,pergumulan mutu spiritual, etik dan moral dan mutu hubungan yang personal dengan Sang Khalik, Pencipta, dan Penyelamat seluruh umat manusia.

Agama merupakan petunjuk perilaku karena di dalam agama terdapat ajaran baik dan larangan yang dapat berdampak pada kehidupan dan kesehatan seseorang. Sebagai contoh, orang sakit dapat memperoleh kekuatan dengan menyerahkan diri atau memohon pertolongan dari Tuhannya (Hamid A.Y., 2000: 2-3).

Secara biologis, para dokter berpendapat bahwa molekulmolekul darah kita mengandung reseptor yang dapat menerima sinyal-sinyal dari otak. Apabila sinyal-sinyal yang diterima adalah tentang keceriaan, ketenangan, kegembiraan, keyakinan dan kepercayaan yang muncul dari nilai spiritualitas dan religisitas, maka proses penyembuhan dapat dipercepat. Hal ini lebih penting daripada tablet-tablet obat yang kita minum (Anand Khrisna, 1999: 144)

\section{Tinjauan Umum Tentang Kebutuhan Spiritual Pasien \\ 1. Pengertian}

Kebutuhan spiritual adalah kebutuhan untuk mempertahankan atau mengembalikan keyakinan dan memenuhi kewajiban agama, serta kebutuhan untuk mendapatkan maaf atau pengampunan, mencintai, menjalin hubungan penuh rasa percaya dengan Tuhan (Carson, 1989). Adapun adaptasi spiritual adalah proses penyesuaian 
diri dengan melakukan perubahan perilaku yang didasarkan pada keyakinan atau kepercayaan yang dimiliki sesuai dengan agama yang dianutnya (Asmadi, 2008: 258).

Maka dapat disimpulkan kebutuhan spiritual merupakan kebutuhan untuk mencari arti dan tujuan hidup, kebutuhan untuk mencintai dan dicintai serta rasa keterikatan dan kebutuhan untuk memberikan dan mendapatkan maaf.

2. Kebutuhan spiritual

Individu sebagai makhluk spiritual mempunyai ciri-ciri sebagai berikut (Asmadi, 2008: 261) :

a. Diciptakan Tuhan dalam bentuk yang sempurna dibanding makhluk ciptaan lainnya.

b. Memiliki rohani/jiwa yang sempurna (akal, pikiran, perasaan dan kemauan).

c. Individu diciptakan sebagai khalifah (penguasa dan pengatur kehidupan) dimuka bumi.

d. Terdiri atas unsur bio-psiko-sosial yang utuh.

Beberapa orang yang membutuhkan bantuan spiritual antara lain (Asmadi, 2008: 263) :

a. Pasien kesepian

Pasien dalam keadaan sepi dan tidak ada yang menemani akan membutuhkan bantuan spiritual karena mereka merasakan tidak ada kekuatan selain kekuatan Tuhan, tidak ada yang menyertainya selain Tuhan.

b. Pasien ketakutan dan cemas

Adanya ketakutan atau kecemasan dapat menimbulkan perasaan kacau, yang dapat membuat pasien membutuhkan ketenangan pada dirinya dan ketenangan yang paling besar adalah bersama Tuhan. Adapun tanda-tanda yang dapat diperhatikan pada pasien yang mengalami kecemasan (Asmadi, 2008: 26) :

\section{1) Cemas ringan}

Kecemasan normal yang berhubungan dengan ketegangan akan peristiwa kehidupan sehari-hari. Respon cemas 
ringan seperti sesekali bernafas pendek, nadi meningkat, tekanan darah naik, bibir bergetar, tidak dapat duduk dengan tenang dan tremor halus pada tangan.

2) Cemas sedang

Ditandai dengan persepsi terhadap masalah menurun sehingga individu kehilangan pegangan tetapi dapat mengikuti pengarahan dari orang lain. Respon cemas sedang biasanya meliputi sering bernafas pendek, nadi dan tekanan darah naik, mulut kering, gelisah, tidak mampu menerima rangsangan, susah tidur dan perasaan tidak enak.

3) Cemas berat

Pada tingkat ini lahan persepsi menjadi sangat sempit dimana individu tidak dapat memecahkan masalah atau mempelajari masalah. Respon kecemasan yang timbul misalnya nafas pendek, nadi dan tekanan darah meningkat, berkeringat, sakit kepala, tidak mampu menyelesaikan masalah.

4) Panik

Pada tingkat ini, lahan persepsi telah terganggu sehingga individu tidak dapat mengendalikan diri lagi dan tidak dapat melakukan apa-apa walaupun telah diberikan pengarahan. Respon panik seperti nafas pedek, rasa tercekik, pucat, lahan persepsi sangat sempit, tidak dapat berfikir logis (Tarwoto \& Wartonah, 2003: 98-99).

c. Pasien menghadapi pembedahan

Menghadapi pembedahan adalah sesuatu yang sangat mengkhawatirkan karena akan timbul perasaan antara hidup dan mati. Pada saat itulah keberadaan pencipta dalam hal ini adalah Tuhan sangat penting sehingga pasien selalu membutuhkan bantuan spiritual.

d. Pasien yang harus mengubah gaya hidup

Perubahan gaya hidup dapat membuat seseorang lebih membutuhkan keberadaan Tuhan (kebutuhan spiritual). Pola gaya hidup dapat membuat kekacauan keyakinan bila ke arah 
yang lebih buruk, maka pasien akan lebih membutuhkan dukungan spiritual (Asmadi, 2008: 256).

\section{Tinjauan Umum Peran Perawat Sebagai Pemberi Asuhan Keparawatan}

Perawat mulai melihat dirinya sebagai praktisi dengan hak tersendiri, mempunyai dan menerima tanggung jawab untuk membuat keputusan tentang praktik keperawatan. Hubungan perawat-pasien diidentifikasikan sebagai tanda dari keperawatan profesional (Ellis, Gates \& Kenworthy, 2000: 78). Perawat adalah orang yang memberikan pelayanan/asuhan keperawatan berdasarkan data hasil pengkajian sampai pada evaluasi hasil baik medik maupun bio-psikososio-spiritual (Ali H.Z, 2002: 43).

Untuk memudahkan dalam memberikan asuhan keperawatan dengan memperhatikan kebutuhan spiritual penerima pelayanan keperawatan, maka perawat mutlak perlu memiliki kemampuan mengidentifikasi atau mengenal karakteristik spiritualitas seperti sembahyang, perlengkapan keagamaan dan bersatu dengan alam (Asmadi, 2008: 254-40).

\section{Metode Penelitian}

Metode pengambilan sampel yang digunakan Sampling NonProbability Sampling yaitu teknik pemilihan sampel yang tidak memberikan peluang atau kesempatan sama kepada setiap unsur anggota populasi untuk dipilih menjadi sampel (Sugiyono, 2005: 60). Peneliti melakukan pengumpulan data melalui penyebaran kuesioner yang disebarkan pada pasien di pelayanan kesehatan. Setelah mendapatkan jawaban langsung dari kuesioner, peneliti akan melakukan analisis data. Peneliti menggunakan uji validitas, reliabilitas, dan normalitas dalam pengujian kualitas data.

Untuk menguji pengaruh marketing mix serta aspek spiritualitas terhadap keputusan pasien berobat di pelayanan kesehatan peneliti menggunakan analisis regresi berganda. Jawaban dari analisis regresi berganda merupakan jawaban dari hipotesis yang menggunakan uji t, F dan $\mathrm{R}^{2}$. 


\section{Pembahasan}

\section{Regresi Linier Berganda}

Model regresi linier berganda untuk variabel Produk $\left(\mathrm{X}_{1}\right)$, Harga $\left(\mathrm{X}_{2}\right)$, Distribusi $\left(\mathrm{X}_{3}\right)$, promosi $\left(\mathrm{X}_{4}\right)$, Aspek Spiritual-Religiusitas $\left(\mathrm{X}_{5}\right)$, serta keputusan berobat $(\mathrm{Y})$ mempunyai rumus persamaan regresi linier berganda sebagai berikut :

$$
\mathbf{Y}=\mathbf{a}+\mathbf{b}_{1} \mathbf{X}_{1}+\mathbf{b}_{2} \mathbf{X}_{2}+\mathbf{b}_{3} \mathbf{X}_{3}+\mathbf{b}_{4} \mathbf{X}_{4}+\mathbf{b}_{5} \mathbf{X}_{5}
$$

Perhitungan pada analisis regresi linier berganda menggunakan program SPSS 17.00 yang menghasilkan persamaan sebagai berikut :

$$
Y=3,169+0,016 X_{1}+-0,056 X_{2}+0,492 X_{3}+0,198 X_{4}+0,235 X_{5}
$$

Dari persamaan regresi tersebut dapat diartikan sebagai berikut:

a. Nilai Konstanta (a)

Dalam persamaan regresi di atas diperoleh konstanta sebesar 3,169 Artinya jika variabel Produk $\left(\mathrm{X}_{1}\right)$, Harga $\left(\mathrm{X}_{2}\right)$, Distribusi $\left(\mathrm{X}_{3}\right)$, produk $\left(\mathrm{X}_{4}\right)$, aspek spiritual religiusitas $\left(\mathrm{X}_{5}\right)$ tidak berubah atau sama dengan nol (0), maksimal pengambilan keputusan berobat responden atau pasien di RSI Kalimasada sebesar 3,169.

b. Koefisien Regresi untuk variable Produk $\left(\mathrm{X}_{1}\right)$

Variabel Produk $\left(\mathrm{X}_{1}\right)$ mempunyai pengaruh positif terhadap pengambilan keputusan berobat, dengan koefisien sebesar 0,016. Yang artinya apabila variabel Produk $\left(\mathrm{X}_{1}\right)$ meningkat sebesar 1 satuan, maka pengambilan keputusan berobat akan naik sebesar 0,016 satuan dengan asumsi citeris paribus.

c. Koefisien Regresi untuk Variabel Harga $\left(\mathrm{X}_{2}\right)$

Variabel Harga (X2) mempunyai pengaruh negatif terhadap pengambilan keputusan berobat, dengan koefisien sebesar 0,056. Yang artinya apabila variabel Harga $\left(\mathrm{X}_{2}\right)$ meningkat sebesar 1 satuan, maka pengambilan keputusan berobat akan turun sebesar 0,056 satuan dengan asumsi citeris paribus. 
d. Koefisien Regresi untuk Variabel Distribusi $\left(\mathrm{X}_{3}\right)$ Variabel Distribusi $\left(\mathrm{X}_{3}\right)$ mempunyai pengaruh positif terhadap pengambilan keputusan berobat, dengan koefisien sebesar 0,492 . Yang artinya apabila variabel distribusi $\left(\mathrm{X}_{3}\right)$ meningkat sebesar 1 satuan, maka pengambilan keputusan berobat akan naik sebesar 0,492 satuan dengan asumsi citeris paribus.

e. Koefisien Regresi untuk Variabel Produk $\left(\mathrm{X}_{4}\right)$ Variabel promosi $\left(\mathrm{X}_{4}\right)$ mempunyai pengaruh positif terhadap pengambilan keputusan berobat, dengan koefisien sebesar 0,198 . Yang artinya apabila variabel promosi $\left(\mathrm{X}_{4}\right)$ meningkat sebesar 1 satuan, maka pengambilan keputusan berobat akan naik sebesar 0,198 satuan dengan asumsi citeris paribus.

f. Koefisien Regresi untuk Variabel Spiritual Religiusitas $\left(X_{5}\right)$ Variabel Spiritual Religiusitas $\left(\mathrm{X}_{5}\right)$ mempunyai pengaruh positif terhadap pengambilan keputusan berobat, dengan koefisien sebesar 0,235. Yang artinya apabila variabel Spiritual Religiusitas $\left(\mathrm{X}_{5}\right)$ meningkat sebesar 1 satuan, maka pengambilan keputusan berobat akan naik sebesar 0,235 satuan dengan asumsi citeris paribus.

\section{Uji Statistik}

a. Uji Parsial (Uji t)

Uji hipotesis ini untuk mengetahui apakah seluruh variabel independen secara parsial mempengaruhi variabel dependen. Pengujian ini dilakukan secara parsial atau individu, dengan menggunakan t statistik untuk masing-masing variabel bebas dengan tingkat kepercayaan 5\%. Untuk menentukan t tabel digunakan rumus sebagai berikut $(\mathrm{dk})=\mathrm{n}-1-\mathrm{k}$. Berdasarkan rumus tersebut hasil perhitungan $t$ tabel pada df (75-1-5) $=$ 69 dengan tingkat kepercayaan 95\% $(\alpha=5 \%)$ uji dua sisi sehingga t tabel sebesar 1,667. Untuk tabel uji t disajikan sebagai berikut: 


\section{Tabel 1}

Uji t

\begin{tabular}{lccc}
\hline \multicolumn{1}{c}{ Variabel } & t hitung & t tabel & Signifikansi \\
\hline Produk $\left(\mathrm{X}_{1}\right)$ & 0,134 & 1,667 & Tidak Sigifikan \\
Harga $\left(\mathrm{X}_{2}\right)$ & $-0,432$ & 1,667 & Tidak Sigifikan \\
Distibusi $\left(\mathrm{X}_{3}\right)$ & 4,221 & 1,667 & Sigifikan \\
Promosi $\left(\mathrm{X}_{4}\right)$ & 2,951 & 1,667 & Sigifikan \\
Spiritual Keagamaan $\left(\mathrm{X}_{5}\right)$ & 3,842 & 1,667 & Sigifikan \\
\hline
\end{tabular}

Sumber : Data Primer diolah 2010

Dari pengujian di atas diperoleh bahwa ada dua variabel yaitu Produk $\left(\mathrm{X}_{1}\right)$ dan Harga $\left(\mathrm{X}_{2}\right)$ tidak berpengaruh signifikan sedangkan variabel yang berpengaruh signifikan ada tiga yaitu Distribusi $\left(\mathrm{X}_{3}\right)$, Promosi $\left(\mathrm{X}_{4}\right)$ dan Spiritual Keagamaan $\left(\mathrm{X}_{5}\right)$.

b. Uji Simultan (Uji F)

Tabel 2

Uji Simultan (Uji F)

ANOVA $^{b}$

\begin{tabular}{lcccccc}
\hline \multirow{2}{*}{ Model } & $\begin{array}{c}\text { Sum of } \\
\text { Squares }\end{array}$ & df & Mean Square & F & Sig. \\
\hline 1 & Regression & 901,353 & 5 & 180,271 & 17,185 & $0,000^{\mathrm{a}}$ \\
& Residual & 723,794 & 69 & 10,490 & & \\
\multicolumn{1}{l}{ Total } & 1625,147 & 74 & & & \\
\hline
\end{tabular}

a. Predictors: (Constant), Spiritual Religiusitas_X5, Promosi X4, Produk_X1, Distribusi_X3, Harga_X2

b. Dependent Variable : Keputusan Berobat_Y

Sumber : Data Primer diolah 2010

Dari pengujian di atas diperoleh bahwa $\mathrm{f}_{\text {hitung }}=17,185>\mathrm{f}_{\text {tabel }}$ = 2,231 maka $\mathrm{H}_{0}$ ditolak dan $\mathrm{H}_{\mathrm{a}}$ diterima. Sehingga dapat disimpulkan bahwa ada pengaruh yang signifikan secara simultan dari variabel produk $\left(\mathrm{X}_{1}\right)$, Harga $\left(\mathrm{X}_{2}\right)$, Distribusi $\left(\mathrm{X}_{3}\right)$, Promosi $\left(\mathrm{X}_{4}\right)$, Spiritual-Religiusitas $\left(\mathrm{X}_{5}\right)$ terhadap keputusan berobat pasien di RSI Kalimasada Bantul Yogyakarta (Y). 
c. Dominasi Pengaruh Variabel Independen (X) Terhadap Keputusan Berobat Di RSI Kalimasada Bantul Yogyakarta (Y) Analisis dominasi pengaruh ini dapat ditentukan dengan melihat besar kecilnya koefisien beta yang dihasilkan dari perhitungan regresi. Dari persamaan regresi diperoleh hasil bahwa koefisien beta variabel distribusi $\left(\mathrm{X}_{3}\right)$ mempunyai nilai tertinggi sebesar 0,409 dan $\mathrm{t}_{\text {hitung }}$ sebesar 4,221. Dengan demikian variabel distribusi $\left(\mathrm{X}_{3}\right)$ mempunyai pengaruh yang paling dominan dalam mempengaruhi pengambilan keputusan berobat pasien di Rumah Sakit Islam Kalimasada Bantul Yogyakarta (Y).

d. Koefisien Determinasi $\left(\mathrm{R}^{2}\right)$

Berdasarkan hasil perhitungan dengan menggunakan SPSS 17.0 maka diperoleh hasil sebagai berikut :

\section{Tabel 3 \\ Koefisien Determinasi (Uji R $\mathbf{R}^{2}$ ) \\ Model Summary ${ }^{\mathbf{b}}$}

\begin{tabular}{lcccc}
\hline Model & R & R Square & $\begin{array}{c}\text { Adjusted R } \\
\text { Square }\end{array}$ & $\begin{array}{c}\text { Std. Error of the } \\
\text { Estimate }\end{array}$ \\
\hline 1 & $0,745^{\mathrm{a}}$ & 0,555 & 0,522 & 3,23879 \\
\hline
\end{tabular}

a. Predictors: (Constant), Spiritual Religiusitas_X5, Promosi X4, Produk_X1, Distribusi_X3, Harga_X2

b. Dependent Variable: Keputusan Berobat_Y

Sumber : Data Primerdiolah 2010

Berdasarkan pada tabel di atas koefisien korelasi ( $r$ ) sebesar 0,745 atau $74,5 \%$. Artinya bahwa antara variabel independen, yaitu variabel produk $\left(\mathrm{X}_{1}\right)$, Harga $\left(\mathrm{X}_{2}\right)$, Distribusi $\left(\mathrm{X}_{3}\right)$, Promosi $\left(\mathrm{X}_{4}\right)$, Spiritual-Religiusitas $\left(\mathrm{X}_{5}\right)$ dengan variabel keputusan berobat $(\mathrm{Y})$ mempunyai hubungan yang kuat, yaitu $74,5 \%$.

Dari perhitungan uji determinasi diperoleh nilai $\mathrm{R}^{2}$ sebesar 0,522 atau 52,2\%. Artinya bahwa variabel independen, yaitu produk $\left(\mathrm{X}_{1}\right)$, Harga $\left(\mathrm{X}_{2}\right)$, Distribusi $\left(\mathrm{X}_{3}\right)$, Promosi $\left(\mathrm{X}_{4}\right)$, Spiritual-Religiusitas 
$\left(\mathrm{X}_{5}\right)$ memiliki kemampuan memberikan kontribusi atau sumbangan pada varians variabel dependen keputusan berobat (Y) sebesar $52,2 \%$, sedangkan variabel-variabel lain di luar model penelitian memiliki kemampuan memberikan kontribusi atau sumbangan terhadap varians variabel dependen keputusan berobat $(\mathrm{Y})$ sebesar $47,8 \%$.

\section{Kesimpulan}

Berdasarkan pada analisis data dan pembahasan data yang telah diuraikan di atas, maka dapat disimpulkan bahwa marketing mix bukan merupakan satu-satunya variabel penentu keputusan pasien untuk berobat di rumah sakit, akan tetapi ada variabel lain sebagai penentunya yaitu aspek spiritualitas-religiusitas. Disamping itu, jika dilihat dari nilai hasil uji determinasi menunjukkan bahwa variabelvariabel lain di luar model penelitian memiliki kemampuan memberikan kontribusi atau sumbangan terhadap varians variabel dependen keputusan Berobat di Rumah Sakit Islam Kalimasada Bantul Yogyakarta (Y) sebesar 47,8\%.

Aspek spiritualitas-religiusitas memiliki kekuatan mempengaruhi keputusan pasien berobat terbesar kedua setelah aspek distribusi dalam marketing mix. Hal ini disebabkan upaya penyembuhan kesehatan aspek spiritualitas religiusitas juga mempunyai pengaruh yang besar. Adanya penyembuhan spiritual dengan cara mendoakan pasien sebelum melakukan tindakan medis atau pengobatan, memutarkan lagu religi atau lagu-lagu rohani serta kelengkapan simbolsimbol keagamaan lain seperti Kitab Suci, pakaian muslim dan kaligrafi Al-Qur'an. Hal ini akan mempengaruhi nilai religius, keyakinan dan kepercayaan kepada Sang Pencipta, disamping itu faktor iman dan kepercayaan seseorang lebih mampu mengatasi dan proses penyembuhan penyakit lebih cepat. Untuk itu dalam menumbuhkan sikap kereligiusan pasien maka diperlukan adanya penerapan aspek spiritual atau bimbingan rohani bagi pasien dalam suatu pengobatan atau pelayanan kesehatan. Sehingga penerapan aspek spiritualitasreligiusitas di rumah sakit sangat diperlukan untuk menaikkan daya tarik pasien untuk berobat. 


\section{Daftar Pustaka}

Ali H.Z. 2002. Dasar-Dasar Keperawatan Profesional. Jakarta: Widya Medika.

Alimul, Aziz H.. 2003. Riset Keperawatan dan Teknik Penulisan Ilmiah, Edisi 1, Jakarta: Salemba Medika.

Asmadi, 2008. Teknik Prosedural Keperawatan Konsep Dan Aplikasi. Jakarta: Salemba Medika.

Bawono, Anton, 2006, Multivariate dengan SPSS. Salatiga: STAIN.

Cofitalan, Ermelindo. 2005. Paradigma Pendidikan Nilai-Nilai Religiusitas Dari Perspektif Iman Katolik. Yogyakarta: Perguruan Tinggi Umum.

Hamid A.Y.. 2003. Buku Ajar Aspek Spiritualitas Dalam Keperawatan. Jakarta: Widya Medika.

Hasan dan M Iqbal. 2002. Pokok-Pokok Materi Pengambilan Keputusan. Cetakan Pertama, Bogor: Ghalia Indonesia.

Hidayat, Komaruddin. 2006. Psikologi Kematian; Mengubab Kematian Menjadi Optimisme, Yogyakarta : Arcan.

http://eprints.undip.ac.id/16960/

http://digilib.ui.ac.id/opac/themes/libri2/detail

http://kabarsehat.com/pengaruh-musik-religi-bagi-kesadaranspiritual.html

http://marsunhas.wordpress.com/2008/05/31/analisis-hubunganantara-marketing-mix-dengan-keputusan-pasienmemanfaatkan-rawat-jalan-rs-dr-wahidin-sudirohusodomakassar/

http://ruangpsikologi.com/psikologi-agama-dan-kesehatan

http://skripsistikes.wordpress.com/2009/05/04/ikmiii46/

http://www.aptik.or.id/artikel/globalisasi-religiusitas-agama-danmahasiswa

http://www.unhas.ac.id/perpustakaan/digilib/ gdl.php?mod=browse\&op=read\&id=_jettytrina -415

Kotler, Philip, 1997. Manajemen Pemasaran. Jilid 2, Alih Bahasa Hendra, Teguh, Dkk. Premhalido, Jakarta.

Krishna, Anand, 1999. Bersama J.P.Vasmani Menggapai Hidup Damai Dan Ceria. Jakarta: PT. Gramedia Pustaka Utama. 
Sugiyono, 2008. Metode Penelitian Bisnis. Cetakan Kedua belas, Bandung: Alfabeta.

Susanty, Nani. 2009. Berjalan Bersama Tuhan.Semarang: Media Injil Kerajaan.

Swasta, Basu. 1999. Azaz-Azaz Marketing. Edisi Ketiga, Bandung: Liberty.

Tjiptono, Fandy. 2001. Strategi Pemasaran. Edisi Ketiga, Yogyakarta: Andi Offset. 